Article

\title{
The New Transparency: Police Violence in the Context of Ubiquitous Surveillance
}

\author{
Ben Brucato \\ Center for Humanistic Inquiry, Amherst College, Amherst, MA, 01002, USA; E-Mail: ben@benbrucato.com \\ Submitted: 13 April 2015 | In Revised Form: 21 July 2015 | Accepted: 10 August 2015 | \\ Published: 20 October 2015
}

\begin{abstract}
Media and surveillance scholars often comment on the purported empowering quality of transparency, which they expect participatory media to promote. From its Enlightenment origins, transparency is related to accountability and legitimacy: its increase is believed to promote these. It has earned a position as an unassailed, prime normative value in contemporary liberal and social democracies. Though still valued, transparency is undergoing change in an era of ubiquitous surveillance. Publics still anticipate governmental and corporate self-disclosure and for such entities to operate visibly; but increasingly, deliberate and incidental surveillance by a range of sources, both institutional and informal, documents the activities of such authorities. More often, civilians participate in producing or amplifying transparency. This article explores this new transparency through a study of U.S. police, focusing on the discourse of police accountability activists and cop watchers to describe how their work adapts traditional notions of transparency. Recognizing the resilience of the police institution despite the new visibility of its violence, the article challenges the presumption that increased transparency will promote institutional reform or crisis. It concludes with a critical comment on prominent expectations that promoting the visibility of police can protect publics and ensure police accountability. This conclusion has implications for other forms of the new transparency, including whistleblowing (e.g., Edward Snowden) and leaking (e.g., WikiLeaks).
\end{abstract}

\section{Keywords}

accountability; Jeremy Bentham; cop watch; legitimacy; media participation; police; Jean Jacques Rousseau; sousveillance; surveillance; transparency

\section{Issue}

This article is part of the special issue "Surveillance: Critical Analysis and Current Challenges", edited by James Schwoch (Northwestern University, USA), John Laprise (Independent Researcher) and Ivory Mills (Northwestern University, USA).

(C) 2015 by the author; licensee Cogitatio (Lisbon, Portugal). This article is licensed under a Creative Commons Attribution 4.0 International License (CC BY).

\section{Transparency, Then and Now}

If I were to mobilize a common trope, describing transparency as a "contested term," it would exaggerate the extent to which the word is used with much care or reflexivity. In fact, transparency is a ubiquitous term but is rarely qualified or operationalized; there is a nearabsence of contention over its meaning though its significance is rarely clear. This article historicizes contemporary accountability practices, with an extended case study of police accountability activism, showing the intellectual and practical connections from these practices to a political concept rooted in Enlightenment political thought. Transparency is also an unassailed and treasured concept, despite its being taken for granted (Birchall, 2011b; Han, 2012). By raising key features of the historical and ideological origins of the concept, the article suggests transparency's inextricable connections to a degraded form of democracy and harbors widely maligned presumptions about information, knowledge, and their connection to political action.

By placing media studies in conversation with the emerging field of surveillance studies, this article demonstrates how the two can contribute to one another. Like the concept of transparency, an enduring 
challenge in each field of inquiry is the presumption that participation in producing media artifacts has selfevidently positive normative value and that it has certain political efficacy. Which politics undergird the position that amateur journalism and participatory media are inherently empowering to publics? Through the use of political theory, this article contributes an answer, one that probes the origins of transparency for guidance and elucidates concerns central in these fields today.

Johnson and Regan (2014) take transparency to mean "a practice that is explicitly targeted to achieve accountability" (p. 1). From its modern normative origins, transparency is visibility combined with some standard of moral regulation that holds individuals or organizations to account. Surveillance adds strategic watching in order to produce that visibility, making available its objects to those agents of a defined regulatory scheme, often performed by or for those with comparatively greater power or authority than those being watched. Political transparency inverts the surveillant gaze, as governments and their agents are made visible to their publics, most often via selfdisclosure, and has its origins in practical development of Enlightenment ideals in the construction of modern democratic states (Birchall, 2011b). Hood (2006) claims transparency is "quasi-religious" in nature, not because it suggests the unmediated visibility of an omniscient god-though it certainly connotes this-but because it represents the pinnacle of righteousness in secular democracies. One behaves transparently in public, among fellow citizens, to be held accountable for speech and action.

In this first section, I begin with the Enlightenment origins of the concept of transparency as it relates to its use in discourse about policing's new visibility. My argument is that policing's new visibility suggests a particular history of transparency, provided below and framing the case study that follows. Andrew J. Goldsmith (2010) first applied John B. Thompson's (2005) conception of the new visibility to police. In the following section, I provide a case study of cop watching. Cop watching emerged in the 1990s as an organized political movement by activists who deliberately recorded police stops in order to document and deter police violence. In this century, cop watching has become increasingly incidental, performed by individuals more often than organizations. People increasingly have a digital camera with them at all times, for instance as a feature on their smart phones. More importantly, police accountability activists promote serendipitous cop watching by civilians, seizing upon already widespread participation in the documentation of everyday life. This case study reveals that the new visibility has adapted the Enlightenment normative and political ideal for transparency, such that the kind of visibility they produce has become identified with political transparency. New activities (e.g., participatory media) and related technologies have become central to how transparency is enabled and produced in many contemporary societies. The new transparency ${ }^{1}$ identifies the ocular visibility provided by digital technologies with the Enlightenment concept, and strengthens its ideological connection to expectations for accountability and legitimacy.

Similar changes in transparency are occurring elsewhere in contemporary discursive and political activity. I close with comment on how transparency is everywhere being reasserted through these activities. In the next section, this history of modern transparency is conceptually bounded by its relevance to the case study. In this regard, I aim to find in the origins of the ideal of transparency the logics that enable the present. More importantly, the case illustrates ways the practice of transparency has changed, specifically by emphasizing the broad public participation in producing transparency, rather relying on the self-disclosure and publicity of political officials and functionaries.

\subsection{The Enlightenment Origins of Transparency}

Though he never used the term, Jean-Jacques Rousseau believed transparency was the pre-civilization condition of the state of nature (Hood, 2006). Nothing in human nature had changed, but in the lost state of nature, people "found their security in the ease with which they could see through one another and this advantage, of which we no longer feel the value, prevented their having many vices" (Rousseau, 1913, p. 132, emphasis added). This seeing through articulates a literal meaning of transparency. For Rousseau, the opaqueness of citizens within the modern city represented a threat to social order. Though Rousseau considered transparent relations among citizens as an intrinsic virtue and opaque relations as an intrinsic vice, he also valued transparency as an instrumental good, as a social condition that is necessary for civic cooperation (Hill, 2006).

Visibility is a precondition for social regulation, enabling virtue and the potential for guarding against vice. In the political realm, visibility entailed publicity. Rousseau held that public servants ought to perform "in the eyes of the public," and "to permit no officeholder to move about incognitio" (in Hood, 2006, p. 7). Here we find in publicity the roots of the contemporary conception of political transparency as a condition where political officials, organizations, and policies are publicly visible in order to be held to account. Public

\footnotetext{
${ }^{1}$ I am not the first to use this term. The Surveillance Studies Centre at Queen's University has had a multi-year research initiative called The New Transparency. I intend no association, neither practically nor conceptually. I use this term to associate John B. Thompson's (2005) concept of the new visibility with the political concept of transparency.
} 
visibility was an assurance against an accumulation of vices among individuals, and this applied just as well to public officials. In moral relations, if transparency is instrumental, a means rather than an end, then accountability is its end. On the other hand, if political transparency is a means, then legitimacy is its end. This legitimacy is-partly, though necessarily-earned through visibly displaying reliable accountability. Fundamental to the Enlightenment project of the democratic state was "to make power visible-to illuminate it" (Andersson, 2008, p. 1). Though early modern states abandoned Rousseau's insistence on direct, participatory republicanism, his desire for transparency by way of publicity was influential. For instance, Kant's adaptation of Rousseau argued that popular acceptance legitimates governance (Davis, 1991), and so political transparency came to be a means of achieving a properly representative government (Birchall, 2011b; Heald, 2006). Transparency was a means of reconciling the "vertical inequality" between law-makers and citizens (Machin, 2012).

Just as important since its inception was the modern state's deep dependence on surveillance (Torpey, 2000). Jeremy Bentham coined the term transparency and with the maxim that "the more strictly we are watched, the better we behave" (in Hood, 2006, p. 9). ${ }^{2}$ This at least nominally applied to public officials, but it practically applied to citizens. While Rousseau's desire was for citizens to self-disclose to one another, Bentham's intention was additionally to maintain social security by compelling their disclosure to the state. Bahmueller explained that for Bentham, "The persons and objects of that [social] world must be weighed and counted, marked out and identified, subjected to the brightness of the public light, the better to be seen by the public eye. Only then could they be controlled and security made possible..." (in Hood, 2006, p. 8). When transparency-as moral regulation-merges with the state, it takes on this police function and as a matter of existential demand. Nicholas de La Mare's "police science" in his Traité de la Police in 1713 articulated strategies for the prevention of disorder that emphasized street lighting and open spaces, optimizing public view and surveillance (Hood, 2006). This early approach to policy shows a technocratic orientation to transparency, where the visibility of citizens was made a function of the built environment. Nonetheless, for Bentham, transparency of public officials was to be assured through reporting practices and was intended to make officials just as subjected to the public as prison-

2 Johnson and Regan (2014) explain that surveillance and transparency are rarely studied under the same lens. That transparency emerges as a discourse with Bentham has a particular irony after Michel Foucault (1979) appropriated Bentham's panopticon, where this prison model functions as a metaphor for the modern societies. ers were in his panopticon. Importantly, the motivation for this ubiquitous transparency was not the assurance of democracy, but of security. Bentham provides a particular reference point in the genealogy of the relatedness of transparency and surveillance, particularly by virtue of their nexus in the state. As I argue below, the new transparency is partly defined by the extent to which transparency and surveillance have become inseparable.

As the modern state developed, political transparency was seen as a prerequisite for or even an assurance of accountability of officials or bureaucracies. Here, it became a result of rules being publicized, procedures being predictable, and the self-disclosure of institutionally empowered actors demonstrating conformity to these standards (Hood, 2006; Tyler, 2006). Since transparency was seen to enable accountability, its successful performance would allow for legitimacy to be reproduced. David Beetham's (1991) influential account of legitimacy explains legitimacy rests on conformity to known rules. Legitimacy, then, requires transparency because rules must be displayed, seen, and understood by publics, and that understanding should result in a perceived coherence between institutional standards and community norms (Levi et al., 2009). These rules rely on broadly shared beliefs or norms, and legitimation is formally expressed through public consent, demonstrated through widespread, voluntary submission to the rule of law and its enforcement, and demonstrated by trust in representatives and agents of government. For instance, Sir Robert Peel's influential principles for policing in 1829 emphasized the role of public consent to be policed through willing cooperation (Chrismas, 2013; Tyler \& Fagan, 2008).

Transparency was core to the idealization of the social pact in modern states. The rule of law demands legitimate governments follow the rules that govern its institutions with the same reliability with which the governed are expected to conform to the rules that govern publics (Tyler, 2006). In democratic societies, legitimacy is important because it fosters self-restraint by the dominant and governing institutions, as well as cooperation and compliance by the governed (Tyler \& Fagan, 2008). This is conditioned on appearances, not simply promises (Tyler, 2006). The performances of institutions must be transparent in that they visibly demonstrate accountability to agreed-upon standards. Without this visibility, institutions cannot be legitimated, and without such legitimacy, they cannot successfully administrate democratic societies. Accountability is not automatic, though the need for legitimacy ensures it. The transparent state by revealing its accountability processes function reliably may only then produce the consent of the governed. Even still, this is a necessary but insufficient condition (Machin, 2012). According to this model, when legitimacy is absent in- 
stitutions crumble in the face of social unrest, or rely on the successful use of violent force to suppress uprisings. The axiom of this model is that without legitimacy, either democracy or governments fail.

While the criticisms of the model are well known (e.g., O'Kane, 1993), it profoundly influenced the constitution of representative democracies. Moreover, the ideal of transparency has inspired-and continues tosocial movements to strengthen democratic citizenship. Such movements should be expected in some measure as a consequence of the degraded status of the citizen relative to the very structures and functions of political institutions fostered by this model.

The following will explain how this modern conception of transparency has been preserved, adapted, and is even amplified within the new transparency, an outcome both of the performances of a surveillance society, and the mythos of what Byung-Chul Han (2012) has called transparenzgesellschaft, or the "transparency society."

\subsection{Transparency in Transition}

If transparency relies on visibility, then the means by which persons are made apparent is crucial. During the latter half of the twentieth century, and especially since, these means have undergone significant transition, and so then transparency is in transition. David Lyon (2001) recognizes, like Rousseau, that "disappearing bodies is a basic problem of modernity" but this problem "has been accentuated with the growth and pervasiveness of communication and information technologies" (p. 15). Surveillance societies are those that "depend on bureaucratic administration and some kinds of information technology" (Lyon, 2007, p. 11) and have turned to deliberate, routine protocols and techniques "to make distant bodies reappear" (Lyon, 2001 , p. 15). Surveillance is now fundamental to the production of visibility.

Transparency not only connotes public visibility, but functions through it. Imaging technologies have become crucial in what is publicly visible, and information and communication technologies have changed the form and scale of the dissemination of images (Thompson, 2005). Without these technologies, visibility is often bidirectional: one available to be seen can see the watcher (Lyon, 2001). Police and surveillance in early modern states relied on techniques more than on technologies for making the public visible for regulatory purposes (Ellul, 1964; Neocleous, 2000; Torpey, 2000). Surveillance etymologically suggests a comparatively powerful entity watching over the actions of subordinated persons (Mann, Nolan, \& Wellman, 2003). Imaging technologies enable this kind of oversight, and are approaching ubiquity in the Global North (Lyon, 2007). The extent to which photographic and video surveillance has come to inform the connotation of surveillance indicates broad recognition that many experience surveillance when the watcher is potentially-and often is-hidden to those being watched (Koskela, 2003). Not only is visibility mediated, but the watchers and the watched negotiate with imaging technologies to modulate their visibility, often, though not always, producing a hidden, remote watcher (Marx, 2009).

The broadly shared experience of being watched has been normalized, such that publics have internalized the surveillant gaze of the state (Foucault, 1979; Marx, 2006). Complying with laws and social norms is partly a result of feeling one is being watched even if the watchers are not apparent. This is the most fundamental aspect of the panopticon metaphor, that publics subconsciously recognize the possibility of being watched at any moment (Lyon, 2006). Panoptic surveillance is an attempt at an efficient solution to when total transparency is infeasible, one intended to manufacture voluntary submission to regulation. A powerful criticism suggests that surveillance regimes are not so totalizing in consequence as the panopticon metaphor suggests, as watchers carefully select among various publics key populations to monitor and regulate (Hier, Walby, \& Greenberg, 2006; Norris \& Armstrong, 1999). This suggests that surveillance has not resulted in the ubiquity that the ideal for transparency would advocate. The ideal of transparency would suggest the surveillant gaze is too discriminatory, and is in need of "democratization" (Hier, 2003).

Surveillance for over a century, and increasingly over the past decades, has involved imaging technologies that produce durable, archivable artifacts: documentations. Not only are watchers able to be hidden to those they surveil, but the visual field is also no longer bound by spatial and temporal co-presence of watcher and watched (Thompson, 2005). Being ephemerally visible is insufficient; transparency now requires a record, and that record must also be archived and available to be accessed. Negotiations over who can see what, how, and when have been the primary substance of discourse about and political contentions over information transparency (Turilli \& Floridi, 2009). New technologies have allowed for hidden and remote viewing of the documentations thereof. Though the ideal of information transparency would call for documentations to be universally available, their distribution has been historically determined or filtered by virtue of political-economic power, discussed further in the next section.

The methods of making bodies visible are various, but the effect of such surveillance is to render the body as an object of classification and record (Bruno, 2011; Crary, 1992; Sekula, 1978). Powerful institutions and the privileged actors therein have access to technologies, techniques, and institutions that enable control over the visible body for the purposes of direction, pro- 
tection, and administration (Lyon, 2001). Deviant and criminal activities are made visible and archived as a result of surveillance in ways it could not have otherwise without imaging and database technologies. Photographic and video surveillance regularly produces evidence used to incarcerate. Those in surveillance societies are familiar with the success of surveillance in making people subject to the disciplinary functions of the criminal justice system. Yet, everyday life also provides experience of the success of surveillance techniques in providing security, productively directing behaviors, and delivering benefits-and occasionally risks unique to surveillance activity, such as what has been named "identity theft."

For the Enlightenment democratic ideal, bidirectional transparency was essential. The state and its populace required for their security both to render the public visible and on popular submission to surveillance. Just as important, the public was meant to watch state actors as a check on their authority. Because states have economic and technical resources to procure and control surveillance technologies, and because they are legally enabled to use them, this bidirectionality exists mostly in principle, rarely in practice. People in surveillance societies have a wealth of experience of the inequity in distribution of surveillance capacities. As we will see below, the unequal distribution of surveillance capabilities is often blamed for inequities in surveillance power. If the public could produce the visibility of state actors with similar ease and at the same scale, then the modern democratic ideal would be made possible by virtue of the enabling technologies.

\subsection{The Neoliberalization of Political Transparency}

In the Enlightenment model of transparency, selfdisclosure and self-restraint is key. Monitoring from outside of institutions was always normatively encouraged, but new technical means are fundamental to the new transparency, in a society that permits no shadows, nothing hidden from view. Visibility produces awareness of official action (Andersson, 2008), and this awareness is seen as an essential foundation for meaningful participation in holding the powerful to account (Mulgan, 2003). Today, the ocular visibility suggested by transparency is much less metaphorical. The new transparency signifies a deliberate, emphatic reassertion of political transparency through two important transitions. The first transition is the informatization of visibility. Physical appearance is no longer the primary means of visibility; it is also produced through the circulation of media content. More crucially, this content is identified with information. Second, the relationship between publics and the state has changed in that transparency is no longer exclusive to self-disclosure by state agents. Birchall explains that transparency now extends beyond voluntary self-disclosure by state ac- tors aspiring to the modern ideal, and now "has taken on the identity of a political movement with moral imperatives" (2011b, p. 62). Recognizing that "transparency as a cultural ideal of modernity" has failed (Teurlings \& Stauff, 2014, p. 4), civilians increasingly participate in producing transparent relations, partly through participatory media, in order to realize this ideal. This movement includes advocacy for open government initiatives by state actors and non-governmental organizations, but also on "the guerrilla fringes of the transparency movement" (Birchall, 2011b, p. 78) are organizations like WikiLeaks and cop watching organizations discussed below. In the following subsections, I detail each of these two transitions.

\subsubsection{Exhibits as Information}

Discussions of transparency, particularly in policy arenas, frequently focus on information transparency and open government initiatives. The technical and organizational activities of realizing broadly shared support for such initiatives have produced a wealth of case studies and in turn debates over causes for failures and about best practices. Though often aimed at producing practical advice, Birchall (2011a) finds these studies can reveal and even criticize the liberal ideological underpinnings of political transparency and the ways in which the concept has undergone neoliberalization.

The reassertion of transparency appears while trust in governments is failing (Birchall, 2011b, p. 66). In order to rebuild trust, ${ }^{3}$ transparency paradoxically offers a particularly neoliberal option of private oversight, one without granting any real political power to publics. Instead, transparency allows members of publics to exert their consumer power in addition to the authority of the ballot vote. In its contemporary ideal, transparency allows the expansion of choices, and for selection to be made by individuals through unhindered access to rich information. As Garsten and Montoya explain, this depicts a "neoliberal ethos of governance" through promoting "individualism, entrepreneurship, voluntary forms of regulation and formalized types of accountability" (in Birchall, 2011b, p. 65).

Governments are expected to be "open," and the criterion of openness is information transparency (Curtin \& Meijer, 2006). In the Open-Source Manifesto, author and former Whole Earther, Robert David Steele connects demands for open government with opensource software and other "open" models of production. The maxim for "open everything": "Demand transparency and truth from every person, every organization, every government. Consider this the modern information-era equivalent of the Golden Rule" (Steele, 2012, p. 56). This recalls transparency as the

\footnotetext{
${ }^{3}$ Trust is often treated as an indicator of legitimacy in empirical research, see Levi, Sacks, Audrey, \& Tyler, 2009.
} 
Enlightenment's secular alternative to religious moral codes. Here we see not only a new credo, but one with a particular Enlightenment legacy being adapted to a new sociotechnical condition. This is not without precedent. Three decades ago, Langdon Winner (1986) critiqued the treatment of information as self-evidently and positively valuable, calling it "mythinformation." In the 1970s and 1980s, the "computer romantics" associated with the Whole Earth movement advanced a techno-utopian view of the promise of information technology to assure participatory democracy, eliminate toil, and assure environmental sustainability. It is this very contingent named and critiqued in Winner's essay, in which he describes mythinformation as grounded in four key assumptions: first, people are bereft of information; second, information is knowledge; third, knowledge is power; and finally, increasing access to information enhances democracy and equalizes social power. What is unique to the contemporary moment is evinced in calls for open government, which demonstrate political transparency is now also a response to "neoliberal audit culture" (Birchall, 2011b, p. 65).

The new transparency encourages beliefs in images speaking for themselves, in cameras as mechanically objective witnesses, and in information as self-evident. Together, the articulation of these beliefs function as a realist narrative (Harris, 2011). The view of mechanical objectivity has deep historical precedent. The first cameras were said to provide "a release from the 'artistic aids' that always threatened to make interpretation a personal, subjective feature of depiction." This mechanical objectivity was "defined by its moralized and automatic status beyond the reach of the artist's hand...boosters of mechanical objectivity...were automatic and as such did not pass through the dreaded dark glass of interpretation" (Galison, 1999).

Technologies that produce indexical images (e.g., photographic cameras) were originally idealized as tools that aided in observation that could communicate "truthful inferences about the world." Crary argues that the camera only briefly maintained this status, which quickly became seen as "a model for procedures and forces that conceal, invert, and mystify truth" (Crary, 1992, p. 29). The new transparency, however, radically repels such cynicism about images, invoking the spokesmen from the Enlightenment who distrusted the corruptible and biased minds of humans and favored the mechanical objectivity of the camera (Galison, 1999). The modern models of mind and perception that see human consciousness as a mirror of the world-"to look means to see, or that to see means to understand" (Burnett, 1995, p. 3)-is reasserted through the new transparency.

A special kind of objectivity is earned by virtue of qualities of new media technologies that produce the new transparency. Yesil explains:
Camera phones... play a significant role in... documenting the misconduct of others, and functioning as tools of surveillance. They reorganize visual documentation and the construction of truth and reality, especially through the emphasis placed on users, and raw, unedited footage. They are generally conceptualized as instruments that we can believe in as neutral recorders of truth and reality, and stand as symbols of neutral vision and transparency mostly because they serve as 'nonhuman witnesses' in the sense that human capacities are irrelevant to their operation. As such these devices have begun to occupy a central position within the matrix of visual documentation and the construction of truth and reality. (Yesil, 2011, p. 285)

The discourse of the new transparency establishes that mediation occurs not as a result of imaging, information, and communication technologies, but by virtue of political interference with or suppression of content. Though traditional norms guiding journalists and media industries have promoted transparency, in that an "essential function of the media in liberal democracies is to legitimate power by holding it to account" (Schlosberg, 2013, p. 213), this ideal has been undermined by political-economic influence. Politicaleconomic approaches to media emphasize economic interests that filter or manipulate content that would otherwise be unproblematic for audiences to commonly receive, absent any need for interpretation, as mere information. Criticism of consolidated media ownership and normative claims that favor pluralization suggest the decentralization of and participation in production and distribution afforded by convergence culture and the network society have inherent democratizing potentials (Bagdikian, 2004; Castells, 2010; Jenkins, 2008; McChesney, 1997). The problem from such perspectives has to do with ownership and control. The propaganda model of Herman and Chomsky (2002) stresses media ownership as fundamental to the content that circulates. The historically concentrated ownership of media by elites aided hegemony and the production of the consent of the governed. Removing the manipulation of communication by hegemonic powers results in content that is stripped down to mere objective information. This perspective has been criticized as a "hypodermic" model of media, where content is "injected" into viewers (Croteau \& Hoynes, 2000).

Openness and sharing, and technologies like social media and clouds, all contribute to information being seemingly liberated from traditional political-economic filters. Documentations travel far, often not fully under control by those responsible for their origination, and "images literally flee from organized control" (Koskela, 2006 , p. 164). Beyond this liberation of information from elite control, as Byung-Chul Han (2012) explains, what is made visible in the transparency society is now 
beyond need for interpretation. What is made visible is objective, pure information, and it is computed via pure machinic logics. In fact, the demand for transparency is invoked most emphatically in conjunction with norms expressing the inherent freedom of information that must be preserved, not infringed upon. Televisibility flattens time and space, makes activities persistently visible, archivable, retrievable. Transparency today denies the occurrence of mediation by rejecting temporal significance. Rather than mediated, transparent images are immediated, in terms of their instantaneity. Temporal actions are subordinated to predictable, timeless access, for ease in monitoring and control. Televisible images are produced, instantly available, stored, accessed, and circulated. Transparency now represents unmediated contact because images become mere information. It permits neither gaps in information nor gaps in one's field of vision.

\subsubsection{Media Participation and Neoliberal Citizenship}

Just when images are simplified as information, the governed are homogenized into a single mass public. The new transparency amends Rousseau's general will with Habermas's public sphere. In the modern bourgeois conception of the public,

"private persons" assembled to discuss matters of "public concern" or "common interest"...These publics aimed to mediate between "society" and the state by holding the state accountable to "society" via "publicity." At first this meant requiring that information about state functioning be made accessible so that state activities would be subject to critical scrutiny and the force of "public opinion." Later it meant transmitting the considered "general interest" of "bourgeois society" to the state... (Fraser, 1993, p. 4)

For Habermas, "the full utopian potential of the bourgeois conception of the public sphere was never realized in practice" (Fraser, 1993, p. 5). A stratified society produced conditions for exclusion from the public sphere and unequal authority within it. With the explosion of the mass media, the increasing scale of industrial production, and the growth of conspicuous consumption, critics like Thorstein Veblen, John Dewey, and Walter Lippmann saw the potential of the public sphere in crisis. They saw, according to Aronowitz, that "knowledge of public events had become impossibly fragmented, everyday life had become increasingly privatized, and, perhaps most importantly, the whole society had become absorbed in an orgy of consumption" (Aronowitz, 1993, pp. 75-76). Informatization provides a resolution, cohering the public once again. The new transparency now sees the instrumental conditions available to realize the full utopian potential of McLu- han's (1965) global village, and media participation is a primary means of civic participation in this space. This ideal model of global citizenship is founded in the coincidence of neoliberalism and informationism (Neubauer, 2011).

Transparency connotes unmediated visibility. In the new transparency, key mediating qualities historically recognized as fundamental to indexical and moving images are eclipsed by emphasizing the qualities of new digital technologies. Incidental or serendipitous recording by civilians and the ubiquity of surveillance cameras removes the mediating effects of editorial selection (Schwartz, 2009; Yesil, 2011). In the past, state and corporate institutions had greater capacity to engage in surveillance, but consumer-grade cameras and social media technologies have made available similar capacities to civilians. The smart phone with its video capability and data-connection permits incidental recording of activities both everyday and anomalous (Yesil, 2011). As Birchall explains, "the availability of technologies of surveillance and information exchange ensures we can be both objects and agents of intelligence" (Birchall, 2011a, p. 11). As costs for consumer electronics have lowered, the threshold to acquire imaging surveillance technologies have increasingly enabled sousveillance, the watching by publics of those with institutional authority. In this way, the modern panopticon is joined by the synopticon, where the many are now-or once again, as in Rousseau's state of nature-able to watch the few (Mathiesen, 1997). Synoptic technologies, Yesil claims, promote visibility in a "'viewer society' where individuals are not only subject to surveillance by government agencies, state institutions, corporations, etc. but also become surveillers themselves as they 'watch' the few and scrutinize them through mass media and television" (Yesil, 2011, p. 285). Increasingly, little is left out of the frame, all shadows have light cast into them-or "night vision"enabled cameras pointed at them. Mobile technologies and other comparatively inexpensive technologies, like digital editing software, lower the financial barriers to entry into media production. Social media platforms function as distribution channels, so barriers to distribute content are also lower (Jenkins, 2008; Yesil, 2011). Viral circulation of content by users of social media and similar platforms makes up for the filtering effects of editorial staffs and the powerful interests that persuade them. These qualities are prioritized by advocates for the democratizing or liberating qualities of new technologies, once again reasserting the camera as an objective witness, now in the hands of billions of users worldwide. Larry Diamond calls these "liberation technologies" and "accountability technologies", because they "provide efficient and powerful tools for transparency and monitoring" (Diamond \& Plattner, 2012, p. 10). "Individuals use their camera phones not only for personal communication," Yesil (2011) ex- 
plains, "but also for documenting the misconduct of others, which leads to the description of such sociotechnological practices as enablers of inverse surveillance that empower ordinary individuals to watch the authorities from below" (p. 285). This sousveillance is claimed to afford the expansion of political, social, and economic freedom (Diamond \& Plattner, 2012).

Given new technological affordances to produce exhibits, today "the lines between reader and reporter, news and opinion, and information and action have all become blurred" (Diamond \& Plattner, 2012, p. x). As such, media users are now simultaneously producers and consumers, or "prosumers" (Jenkins, 2008), who participate in the production of transparency. Anthony and Thomas (2010) explain "participatory media technologies that allow for the creation and distribution of user-generated content overturn traditional notions of all-powerful news media that define and restrict a largely passive audience" (p. 1283). Policymakers and scholars frequently express belief that such digital tools have profound political impacts, and emphasize the role played by access to alternative and independent sources of information enabled by unfiltered access to the internet (Etling, Faris, \& Palfrey, 2010). That the "arena for political commentary and competition is more fast-paced, more decentralized, and more open to new voices and social entrepreneurs than ever before," is taken as evidence that the ease and efficiency in generating and dispersing a diversity of media content is inherently democratizing (Diamond \& Plattner, 2012 , p. x). As the digital divide in surveillance technology is closing (Mann et al., 2003, p. 335), a singular public is both enabled and expected to be media prosumers as a key performance of their citizenship (Dean, 2008).

When institutions themselves are deemed inappropriately transparent, civilians increasingly-enabled by cheap and abundant digital technologies-monitor institutions and official actors. Watchdog media checks and augments information provided by the selfdisclosure of officials and institutions. More recently, civilians are active as watchdogs of their own sort, not only as intentional, planned activity, but also through incidental, happenstance documentation of official conduct (Anthony \& Thomas, 2010). Civilians monitor wildlife, air and water quality, and produce similar environmental indices (Jalbert, Kinchy, \& Perry, 2014; Kinchy, Jalbert, \& Lyons, 2014; Kinchy \& Perry, 2012; Ottinger, 2010). This activity is done as a form of redundancy, to quantitatively improve extant data or enhance quality of knowledge thus produced through repetition. This activity may be done where extant data is deemed deficient, either of poor quality or limited in quantity, to fill in gaps of knowledge otherwise left incomplete in quality or coverage. Finally, it can be undertaken when existing monitoring is deemed negligent, an oversight. In the new transparency, anything that escapes view is a source of risk or danger by virtue of its invisibility. Civilian voluntarism increasingly supplements or replaces activity historically in the purview of governments. This may be done, as we might expect, when there is a breakdown in trust among publics for the institutions that are or would usually be tasked with such surveillance. Redundant monitoring is especially indicative of this lack of trust. But it is also activity promoted by neoliberalization, as government agencies scale back due to funding and other cuts. Civilian monitoring steps in where government surveillance is deficient, negligent, or underfunded. In such a situation, the production of transparency by civilians develops a quality of civic participation, and in democratic societies, this confers a positive normative quality to the activities of monitoring (Dean, 2008). To produce transparency is to be a good citizen.

Since the new transparency ascribes absolute, positive value to visibility, the technologies and techniques that render bodies visible to surveillance produce power, and presumably with symmetry. This discourse frames imaging, communication, and information technologies as plastic, amenable to serving and empowering any interests. Surveillance activity is not exclusive to powerful institutions and actors who derive authority from these. The new transparency encourages a view of surveillance that is neutral, one where watching from below is productive of new powers for those outside the traditionally recognized structures of authority. Despite reliable substantiation for expectations that these new capabilities foster consequential political participation, the pervading doctrine of the new transparency allows such expectations to persist in absence of a demand for evidence supporting them. Even the most hopeful advocates for liberation technology (see, e.g., Diamond \& Plattner, 2012) recognize the limited or equivocal evidence supporting their descriptions of these technologies as such. Here, the quasi-religious, doctrinal quality of the new transparency is revealed: it is, at its core, a faith rooted in history, ritually reproduced through insistence upon its efficacy and popular use predicated on this efficacy.

\section{The New Transparency of Police}

The prior section details the intellectual origins and social shaping of a concept that figures centrally in discourse about of policing's new visibility (Brucato, 2015; Goldsmith, 2010; Thompson, 2005). Transparency relies on a visibility produced by surveillance. During the past century, the use of camera surveillance became crucial to the maintenance of order just as citizens were increasingly tasked with producing transparent relations. In this section, I explain these two changes coincide with the new transparency of police. Using a situational analysis (Clarke, 2005), my research began by archiving videos documenting police violence, profil- 
ing organizations that circulated these on social media, and building situational maps that identified key themes in pertinent discourse. My primary objective was to explain the proliferation of these videos. After years of studying discourses involving them, the theme of transparency was found to clearly pervade discussion of these videos and of policing's visibility (Boyatzis, 1998). I established an archive including scholarly research, public press articles, online and social media posts by activists, and supplemented these with original data from interviews and field notes. From this archive, I have selected and provided below key content that establishes the role played by modern notions of transparency and the discursive work in contemporary political contentions about police violence that are modifying these notions to develop the new transparency.

\subsection{A New Era of Police Visibility}

In 1991, the beating of Rodney King by Los Angeles Police Department (LAPD) officers was incidentally and covertly video recorded. Its release exposed the brutality of policing beyond the communities that chronically experience such violence (Skolnick \& Fyfe, 1993). The video, which Mann and colleagues refer to as "probably the best-known recent example of sousveillance" (Mann et al., 2003, p. 333), made visible what the Christopher Commission later determined was routine police practice by the LAPD. This genetic moment in the history of incidental video documentation of police violence demonstrates the discourse of the new transparency. Los Angeles attorney and former State Department official, Warren Christopher, headed an independent investigation into a pattern of civil rights violations and violence by the LAPD. He wrote this Commission

owes its existence to the George Holliday videotape of the Rodney King incident. Whether there even would have been a Los Angeles Police Department investigation without the video is doubtful, since the efforts of King's brother, Paul, to file a complaint were frustrated, and the report of the involved officers was falsified. Even if there had been an investigation, our case-by-case review of the handling of 700 complaints indicates that without the Holliday videotape the complaint might have been adjudged to be "not sustained," because the officers' version conflicted with the account by King and his two passengers, who typically would have been viewed as not "independent." (Independent Commission on the Los Angeles Police Department, 1991, p. ii)

Yesil (2011) explains the lasting significance of the Rodney King video, writing it "has served as one of the first and most widely-viewed examples of the power of mobile recorded image. The message of the Rodney King tape was that no person, institution or organization was immune from being monitored" (p. 280). The tape's power, she argues, was earned through its contents being widely disseminated and generating unprecedented public awareness about police violence. Responding to the Rodney King controversy, Skolnick and Fyfe (1993) argued that, "in the absence of videotapes or other objective recording of gratuitous violence, brutality rarely causes public controversy and is extremely difficult to prove" (p. 19). Here, not only is video objective, able to "prove" what happened, but public controversy is conditioned on this particular mode of exhibition. Crucial for the new transparency is that the value of this video remains even though the officers who brutalized King were exonerated in criminal court.

At the turn of the century, Regina Lawrence (2000) claimed that "most instances of police use of force are spontaneous, and the vast majority do not occur in the glare of television lights" (p. 14). Just a decade later, Diamond explained "incidents of police brutality have been filmed on cellphone cameras and posted to YouTube and other sites, after which bloggers have called outraged public attention to them" (Diamond \& Plattner, 2012, p. 10). Now, Goldsmith (2010) explains, "video is the new reality" with "policing's new visibility." Jeffries (2011) argues, "cell phone surveillance" has "'turned on its head' the idea that the citizenpolice officer relationship is an asymmetrical one" (p. 74). In just a decade, the game has seemingly changed, and the new technologies (e.g., mobile phones, microblogging and other social media) that produce and distribute this surveillance are credited for having changed the power dynamics in political culture. Disguising or hiding illegal or other offensive behavior is not as fully within the command of officers and agencies as they had been in the past. While acknowledging he is unclear about how this visibility will offer it, Goldsmith (2010) nonetheless finds it "highly probable that the new capacities for surveillance of policing inherent in these technologies may increase the police's accountability to the public" (p. 915).

Yesil (2011) claims that the use of cellphones to document the misconduct of others leads "to the description of such socio-technological practices as enablers of inverse surveillance that empower ordinary individuals to watch the authorities from below" (p. 285). Each new video documenting police brutality is said to produce "ruptures" in the "social fabric" because they bring up past injustices, as with the beating of Rodney King (Anthony \& Thomas, 2010, p. 1292). In 2009, dozens of witnesses watched BART (Bay Area Rapid Transit) Police Officer Johannes Mehserle shoot Oscar Grant in the back, killing him while another officer restrained him, prone on a train platform in Oakland, California. The incident was video recorded by several of these witnesses. Since then, dozens of beatings and killings 
by police have been documented by civilians on their cell phones, including Eric Garner being choked and suffocated by New York Police Department Officer Daniel Pantaleo in July 2014; Charly "Africa" Leundeu Keunang being shot and killed by a LAPD Sgt. Chand Syed and Officers Francisco Martinez and Daniel Torres in February 2015; and Walter Scott being shot and killed by North Charleston Police Officer Michael T. Slager in April 2015.

According to the discourse of the new transparency of police, the ability for civilians to produce policing's visibility empowers them in ways previously never imagined. These powers emerge from the mechanically objective qualities of cameras and the self-evidenteven scientific-qualities of the media they produce. New popular abilities to make truthful claims backed by documentation and to thereby hold officials accountable are importantly joined by a protective power: to prevent police violence from being used against other community members or oneself (Brucato, 2015). This preventative power, provided by the visibility cameras produce, recalls Bentham's claim that behavior improves when people are strictly observed.

\subsection{Cop Watching}

This case is provided to demonstrate how the discourse of transparency functions in contemporary political contention. Regardless of the validity of the Enlightenment ideal for transparency in adequately describing the actual functioning of contemporary democracies, this conception lives on in the discourse and political activities of advocates for transparency. The following case study focuses especially on particular groups of such advocates: self-described "police accountability" activists who video record police and advocate that civilians also engage in such documentation. Cop watching has come to describe two kinds of activities. Cop watching has always referred to organized, intentional documentation of police by community groups; but it increasingly also describes the incidental, happenstance documentation by independent civilians (Huey, Walby, \& Doyle, 2006; Toch, 2012; Wilson \& Serisier, 2010). The modern ideal of transparency would suggest that making visible the administration of the law would protect civilians from its excesses, because transgressions would be subjected to accountability-or otherwise administrators would lose legitimacy. In my original interviews with them and in their public statements, cop watchers describe their motivations for making policing more visible. Like Pete Eyre, a co-founder of the organization Cop Block, who says "I'm a definitely a big advocate of transparency" (WeAreChange, 2013), these police accountability activists leverage what they see as the police's need for legitimacy to promote accountability.

On August 9, 2014, in Ferguson, Missouri, while on duty a white police officer, Darren Wilson, shot and killed Michael Brown, an unarmed, 18-year-old Black man. While this incident captured the attention and inspired the mobilization of existing activists and organizations across the country, it also produced a spontaneous uprising in Ferguson that continued for months. David Whitt lives in the housing project where Brown was killed. Despite not having an activist history, he became active daily in political agitation in his community. Whitt was both protesting the killing, but also engaging in efforts to constructively respond to what he saw as a pattern of excessive force, and particularly against people of color. He founded the Canfield Watchmen, who engaged in daily cop watch "patrols" to record police stops. With the support of a crowdfunded campaign by We Copwatch, the Canfield Watchmen distributed over one hundred wearable video cameras to area residents for them to serendipitously record police stops on an individual basis.

Cop watchers see their activities as preventing the invisibility of police violence. Like Rousseau, they see opacity as a vice itself and one that encourages further unethical behavior, often with brutal or deadly consequences. Video keeps individual officers honest. Those who transgress can be targeted as on this basis by cop watchers. Pete Eyre of the police accountability organization, Cop Block, claims because "it's individuals who act...it's individuals who are responsible for their actions" (personal communication, February 17, 2015). Here we see transparency functioning in its modern normative sense: enabling the mutual regulation of individual behavior.

Community organizer and independent journalist, Gregory Malandrucco, articulates that camera surveillance enables the kind of bi-directional transparency Bentham preferred:

Today, video captures not only civilians acting beyond the bounds of legality against the state and its laws, but also egregious instances of police officers breaking the very laws they are sworn to uphold. Technology presents us with the unforeseen potential to hold public officials accountable for their actions in swift and certain terms, as equal members of society... (Malandrucco, 2012)

Civilian participation in media production places civilians on more equal footing with police and other state actors. This view demonstrates in action the idea that this kind of transparency works to legitimate vertical inequalities in representative democracies. More importantly, if officials, functionaries, and other agents of the state are insufficiently visible, individual citizens can now offer the corrective. Jeffries writes that "using a cell phone camera to monitor police work is a relatively easy way to participate in the democratic process. Doing so gives people a sense of efficacy; that they can impact 
what the government does" (Jeffries, 2011, p. 74).

Given the new transparency, the content of these videos is self-evident and objective, prior to or even forbidding any interpretation. Eyre presents transparency as a technically-enabled quality: "If I say 'Hey, this just happened,' they don't have to try to determine if I'm being factual or not." Because "the lens of the camera is objective," he says, "People don't have to know me, or trust me... They can just look at the video." (WeAreChange, 2013).

Cop watchers see themselves not only as participating in viewing the articulation of state power, but also as producing new popular power. The belief that popular media production and circulation can produce power is grounded in three claims. The first is because it circumvents filtering effects enabled by the political economic power of the mass media. Matt Agorist of The Free Thought Project claim that unfiltered content generation and circulation is "changing the world." "Technology and the internet," he writes, "is giving way to amateur reporters putting out unfiltered and unedited news. This is the future, this is how REAL change is brought about; not from fat cats in nice suits lying to you" (Agorist, 2014). As Eyre explains:

We live in a time now with technology, where we can go around the would-be censors that really thrive on the control and access to information. Today with the internet and other technologies we can really bypass those gatekeepers and support each other...(personal communication, February 17, 2015)

Second, media produced by civilians shapes the agenda in political forums and in mass media reporting. Grant A. Mincy of Center for a Stateless Society claims "new technology, independent media and good old human communication" have provoked increased attention by mainstream news outlets that are following agendasetting happening at the grassroots. "We are connected, we talk, we control the public arena and we make stories go viral," he explains. "In the face of increased violence folks are taking to social media to spread news and directly confront state power" (Mincy, 2013). Finally, because of the supposed civilizing quality of transparency, cameras provide their users with protective power. Wendy McElroy (2010) claims "cameras have become the most effective weapon that ordinary people have to protect against and to expose police abuse."

\subsection{Exhibiting Unaccountability}

Sen (2010) applies the modern triad of transparency, accountability, and legitimacy to police, explaining that in a democratic society police are accountable to the people, and also have "a proximate responsibility to the law of the land which expresses the will of the people" (p. 1). He further maintains that "the police should be transparent in its activities. Most of the police activities should be open to scrutiny and subject to reports to regular outside bodies" (Sen, 2010, p. 9).

Prenzler and Ronken (2001) reviewed several decades of research throughout the Anglophone world to systematically review predominating models of police accountability. Initial police accountability included accountability to law and to elected officials, to which was later added internal investigations and review by external agencies. Cop watchers may advocate using video footage to ensure greater accountability through such processes. However, they add to or replace these processes by promoting the withdrawal of police legitimacy by publics.

Cop watching, Jeffries (2011) contends, "has introduced an element of accountability that heretofore has been absent" (p. 74). By filming police, "unknown cameramen and women lived out high democratic ideals" through this mode of bearing witness (Meyer, 2015). Acknowledging "that civilian-held cameras are [not] always effective at securing a conviction," Meyer (2015) cites the example of Eric Garner, killed by New York Police Department Officer Daniel Pantaleo in Staten Island on July 17, 2014. The killing of Garner was video recorded, but no officers were indicted by the Richmond County Grand Jury. Nonetheless, as in the Rodney King incident, the significance of video is that we know. After all, in the new transparency, to see is to know (Han, 2012). According to contemporary perspectives that venerate transparency, political problems are a result of a deficient or incomplete set of information to be solved through accumulating more and better information (see Winner, 1986).

According to the discourse of the new transparency, once police-civilian interactions are made visible, accountability is the likely or certain outcome. In his report on police repression of Occupy Wall Street protests, Harmon Leon (2011) wrote that "cell phones and social media are the great equalizers in keeping law enforcement accountable." Similarly, Carlos Miller (2014) of the advocacy group, Photography Is Not A Crime!, explains that "justice prevails every once in a while," but "only because it was all caught on video." However, if accountability is not reliably demonstrated, many cop watchers believe this will undermine the police institution by causing a crisis of legitimacy. They agree with journalists like Matt Taibbi (2014), who claims that as a result of the deaths of Michael Brown in Ferguson and Eric Garner in New York, "the police suddenly have a legitimacy problem in this country." Friedersdorf (2014) contends that "the police continue to lose the trust of the public, due largely to documented instances of bad behavior by fellow officers, as well as law enforcement's longstanding inability to police themselves."

Meyer (2015) acknowledges a poor model for justice requires police accountability "rely on someone always standing nearby with a smartphone. But the 
process of ascertaining the truth of the world has to start somewhere." Many cop watchers are not only aimed at holding individual officers responsible for transgressions. For Eyre, filming is also desirable

to make clear a pattern of unaccountability that's built into the so-called justice system. The idea that it's just a few rogue people that are doing something is not true.... If people see this as a pattern then.... [this will undermine] the legitimacy that they grant to these institutions, or their own willingness to call them and utilize them, or deferment to them, or even the funding of their apparatus... (personal communication, February 17, 2015)

Through accumulation of videos, these will allow the public to see the depicted incidents are not isolated or exceptional, but instead form a pattern revealing the normal function of police. If publics routinely see videos followed by a failure to demonstrate institutional accountability, they would retract the legitimacy they grant to these institutions. "That's ultimately to me what's necessary to have a change" explains Eyre (personal communication, February 17, 2015).

As Rojek, Alpert and Smith (2012) observe, sousveillance media documenting policing activity "provide the public with a snapshot of what the police do" (p. 302). Lersch and Mieczkowski (2005) explain videocameras and media attention may foment distrust and fear of police. This exposure could create the impression that police violence is increasing, when in fact "violent police behavior has a long history, dating back to the early years of law enforcement" (Lersch \& Mieczkowski, 2005, p. 553). ${ }^{4}$ Because "cell phone camera surveillance of police officers is exposing behavior that some police officers have gotten away with for years" (Jeffries, 2011, p. 73), routine problems of policing are now subject to popular oversight.

When transparency fails to produce accountability, when it does not fulfill the promise of protection, the modern transparency-accountability-legitimacy triad would suggest that legitimacy is certain to fail. Many cop watchers wish to undermine the legitimacy of the police institution, so they believe making its essential violence visible will result in a withdrawal of legitimacy, and this alone will force change. This is why these cop watchers choose media circulation as their primary activity, rather than more traditional means of community organizing to issue demands to or to directly confront governmental institutions. The battle is over legitimacy, and transparency is the tactic of choice.

\section{The Resilience of Police}

Despite the increased visibility of policing (Goldsmith,

${ }^{4}$ For a detailed history, see Brucato (2014).
2010), declining violent crime rates (Truman \& Planty, 2012) and increased officer safety (Center for Officer Safety \& Wellness, 2014), officer use-of-force incidence does not appear to be waning (Alpert \& Dunham, 2000, $2004,2010)$. Furthermore, officers are equipped with more weaponry to use (Kraska \& Kappeler, 1997) in more striated continuums of force (Walker, 2005). In the past decade, police have killed thousands of Americans, and yet only 54 police have been criminally charged for the killings (Kindy \& Kelly, 2015). Of those cases that are resolved, less than a third were convicted. These police were sentenced to serve about three years in jail or prison, on average. Oscar Grant's killer, former Officer Johannes Mehserle, served just over a year and a half in jail. The rapid growth in police monitoring should leave us skeptical over claims made regarding its political efficacy. Police know they are now visible, and yet the police institution and its use of violence do not appear to be changing in any fundamental way-certainly not in the ways most cop watchers expect. For all the talk about the popular empowerment caused by cheap imaging and communication technologies, the police institution remains resilient.

Though transparency is widely believed to produce the possibility of accountability (Mulgan, 2003), and is therefore productive of popular power (Birchall, 2011b), this expectation is frustrated by the actual outcomes of documenting police violence. The very proliferation of such media speaks to the limitations of visibility as a protective power. Roger Holliday was hidden in his apartment while LAPD officers beat Rodney King at night in 1991. However, the more recent 2008 video-recorded beating of Michael Cephus showed the close proximity of several citizens filming police during daylight as one officer struck Cephus so hard with a baton that the officer lost his grip on it and it rolled across the street. Hurst Texas Police Department Officer Disraeli Arnold taunted a cameraperson as he brutalized and threatened to kill an already restrained 17year old, Andrew Rodriguez, in 2012. After kneeing Rodriguez in the head and shouting "Move and die!" he marched him, handcuffed, past the camera and shouted-without prompting-his badge number into the camera. Following the killing of Michael Brown, months of sustained protests in Ferguson, Missouri, sporadic related protests throughout the United States, President Barack Obama signed a bill to fund the adoption of 50,000 on-officer wearable cameras (Brucato, 2015). Rather than demonstrating accountability, publics were offered more transparency.

Cop watching exemplifies the adaptation of modern transparency to contemporary conditions. The new transparency retains qualities from its Enlightenment origins, and renews its conceptual and practical connections to accountability and legitimacy. Emphasizing transparency's connection to ocular visibility, now visibility paradoxically benefits from its mediation, be- 
cause it allows for televisibility and archivability while simultaneously maintaining its objectivity. The affordances of new technologies allow for both access and instantaneity. Mediation only retains its positive qualities that allow for transcending the limits of time and distance, providing an archivable object with its own persistent access, but also lending direct access to what really happened. Since documentations are not edited or filtered by editorial staffs working for multinational megacorporations, raw footage gives amplified access to what Szarkowski (2007) calls "the thing itself." With streaming video and Tweeted photographs, this can happen instantaneously. Time is suspended, and so images are no longer the embodiment of an afterlife, but rather a sign that the metaphors of life and death do not apply to media. Everything is now. Transparency is presence.

The new transparency undergirds the political strategies not only of most activists and other civil society groups focusing on police violence, but it also motivates considerable political activity on matters of crucial social and environmental importance. Not only do civilians watch police, but they document many aspects of the built and natural environment, both their friends and governmental institutions. Most of all, civilians champion the courage of whistleblowers; WikiLeaks and Edward Snowden have revealed to the world the extensive functions and seemingly shocking outcomes of the military and security apparatus, and the leakers are lauded as heroes.

In his influential conceptualization of "the new visibility," Thompson argues, "mediated visibility is not just a vehicle through which aspects of social and political life are brought to the attention of others: it has become a principal means by which social and political struggles are articulated and carried out" (Thompson, 2005 , p. 49). He explains this new visibility is a "doubleedged sword." When cameras are ubiquitous and the internet lowers thresholds to reach audiences, both the governed and the governing are exposed. Yet clearly, both edges of this blade do not always cut the same or as deeply.

What might explain the excitement over WikiLeaks, cop watching, and similar struggles for visibility? Setting aside for a moment common concerns about privacy, might it be that many civilians find in surveillance the possibility of alleviating anxieties by returning to what Rousseau saw as our lost state of nature? New technological affordance allow us to see through one another, to make actions apparent in public so people can be held to popular account. But this ideal does not square with current political realities. We might meet the precondition of transparency, the means treasured today as in the early modern period; but the ends of this ideal-a democracy governed through broad participation by all publics, where the powerful are held to account-is far from a reality. Perhaps this footage provides not a transparent lens into reality, but a mirror reflecting back on its viewers. As Žižek (2011) wrote about WikiLeaks, the shame these disclosures produce is not only directed toward public officials and functionaries, but also back at ourselves "for tolerating such power over us." More importantly, this shame "is made more shameful by being publicised." This, of course, is simply a restatement of the transparencyaccountability-legitimacy model: that there is no authority except that which persists with public consent.

Videos documenting police violence in the United States most often depict Blacks being brutalized, often by white officers, and this squares with long-established patterns in police outcomes (Brucato, 2014). Though public disapproval of police agencies may increase after publicized incidents involving charges of brutality, this disapproval does not become entrenched, especially not among whites (Weitzer, 2002). Not only is there a strong majority approval of police in the United States, this approval is not impacted among whites even when they believe police are brutal and racist (Thompson \& Lee, 2004). In keeping with Sir Robert Peel's belief that the public consent and trust are necessary for successful policing, criminological researchers presume its necessity despite so rarely finding it (Reiner, 2010), especially among those populations most intensively policed-Blacks living in segregated urban neighborhoods (Kane, 2005).

The United States is not comprised by a single, homogeneous mass public that together grants its consent to public institutions-neither is any other contemporary liberal-democratic nation, for that matter. Rather the United States was historically and is currently deeply divided along the color line. Joel Olson (2004) referred to the United States as a "white democracy" on the grounds that it has two practical political orders: democracy for white citizens and tyranny for everyone else. This division has always been crucial to the police mandate (Brucato, 2014). While some documented incidents of police brutality have prompted uprisings, these have been few in number, unsustained, and resulted in little more than nominal commitments by public officials to improved police accountability. The rebellions in Ferguson in 2014 and in Baltimore in 2015 were exceptional on many grounds. Importantly, mostly poor, Black nonactivists populated both uprisings, and they remained militantly active in the streets for weeks. Police were shown on amateur video and mainstream media using military vehicles, weapons, armor, and other equipment to suppress both rebellions. When a defined segment of the fragmented U.S. population then demonstrated a persistent lack of consent to the brutal policing that is an ambient presence in their lives, police suppressed this rebellion using military weapons and tactics and in full view of broader publics.

The new transparency casts new technologies as 
enablers of a "global village," allowing a universal humanity to transcend sociospatial divisions, of which the color line is but one indicator. The persistence of this presumption not only avoids the inability for publics to efficaciously act on the basis of such a capacity. This presumption also reinforces what Cheliotis (2010) calls "narcissistic sensibilities and practices, either by presuming that the included already possess a kindheartedness in wait only for specific directions, or by framing 'others' as human only insofar as their stories reflect our own emotional world" (p. 172). The transparency-accountability-legitimacy model presumes an undivided public, perhaps permitting some inequality within it, but not capable of accounting for the categorical exclusion or domination of an entire population.

The new transparency is grounded in the mistaken idea that documentations are self-evident, and that this divided population would make the same sense of videos documenting police violence. As Butler (1993) argued with reference to the Rodney King case, not only are U.S. populations racialized, but, in part because of this, the visible is itself a racially contested terrain. Transparency casts video as capable of speaking for itself. When partisans expect video to function this way, they neglect the political task of engaging in public speech that would provide an antiracist, counterhegemonic interpretation against the dominant reading that interprets police as providers of security and those most intensively policed-people of color, and especially young Black men-as threats to the social order.

\section{Acknowledgments}

Thanks to Crina Archer, Langdon Winner, and Nancy D. Campbell for crucial comments on earlier drafts. Thank you to three anonymous reviewers and the editors for close reading and helpful commentary. I appreciate the assistance of Jennifer Mann in finalizing the copy. This research was partly conducted while supported by the Humanities, Arts, and Social Sciences Fellowship at Rensselaer Polytechnic Institute.

\section{Conflict of Interests}

The author declares no conflict of interests.

\section{Bibliography}

Agorist, M. (2014, January 20). How individuals with smartphones and cameras are changing the world by filming corruption. The Free Thought Project. Retrieved from http://thefreethoughtproject.com/ individuals-smartphones-anhd-cameras-changingworld-filming-corruption.

Alpert, G. P., \& Dunham, R. G. (2000). Analysis of police use of force data. Washington, DC: National Institute of Justice.
Alpert, G. P., \& Dunham, R. G. (2004). Understanding police use of force: Officers, suspects, and reciprocity. New York, NY: Cambridge University Press.

Alpert, G. P., \& Dunham, R. G. (2010). Policy and training recommendations related to police use of CEDs: Overview of findings from a comprehensive national study. Police Quarterly, 13(3), 235-259.

Andersson, K. (2008). Transparency and accountability in science and politics: The awareness principle. New York, NY: Palgrave Macmillan.

Anthony, M. G., \& Thomas, R. J. (2010). "This is citizen journalism at its finest": Youtube and the public sphere in the oscar grant shooting incident. New Media \& Society, 12(8), 1280-1296.

Aronowitz, S. (1993). Is democracy possible? The decline of the public in the American debate. In B. Robbins (Ed.), The phantom public sphere (pp. 7592). Minneapolis: University of Minnesota Press.

Bagdikian, B. (2004). The new media monopoly. Boston, MA: Beacon Press.

Beetham, D. (1991). The legitimation of power. Atlantic Highlands: Humanities Press International.

Birchall, C. (2011a). Introduction to "Secrecy and Transparency": The Politics of Opacity and Openness. Theory, Culture \& Society, 28(7/8), 7-25.

Birchall, C. (2011b). Transparency, Interrupted: Secrets of the Left. Theory, Culture \& Society, 28, 60-84.

Boyatzis, R. E. (1998). Transforming qualitative information: Thematic analysis and code development. Thousand Oaks: Sage Publications.

Brucato, B. (2014). Fabricating the color line in a white democracy: From slave catchers to petty sovereigns. Theoria: A Journal of Social and Political Theory, 61(141), 30-54.

Brucato, B. (2015). Policing made visible: Mobile technologies and the importance of point of view. Surveillance \& Society, 13(3/4).

Bruno, F. (2011). A brief cartography of smart cameras: proactive surveillance and control. In R. J. Firmino, F. Duarte, \& C. Ultramari (Eds.), ICTs for mobile and ubiquitous urban infrastructures: Surveillance, locative media and global networks (pp. 257-271). Hershey, PA: IGI Global.

Burnett, R. (1995). Cultures of vision: Images, media \& the imaginary. Bloomington: Indiana University Press.

Butler, J. (1993). Endangered/endangering: Schematic racism and white paranoia. In R. Gooding-Williams (Ed.), Reading Rodney King/Reading urban uprising (pp. 15-22). New York: Routledge.

Castells, M. (2010). The rise of the network society: The information age: Economy, society, and culture, volume I (2nd ed.). Malden: Blackwell Publishing.

Center for Officer Safety and Wellness. (2014). 2013 Line-of-duty officer deaths: An overview. Alexandria, VA: International Association of Chiefs of Police.

Cheliotis, L. K. (2010). The ambivalent consequences of 
visibility: Crime and prisons in the mass media. Crime Media Culture, 6(2), 169-184.

Chrismas, R. (2013). Policing in the 21st century: $A$ frontline officer on challenges and changes. Montreal, QC: McGill-Queen's University Press.

Clarke, A. E. (2005). Situational analysis: Grounded theory after the postmodern turn. Thousand Oaks, CA: Sage.

Crary, J. (1992). Techniques of the observer. Cambridge, MA: MIT Press.

Croteau, D., \& Hoynes, W. (2000). Media/society: Industries, images, and audiences. New York: Pine Forge Press.

Curtin, D., \& Meijer, A. J. (2006). Does transparency strengthen legitimacy? A critical analysis of European Union policy documents. Information Polity, 11, 109-122.

Davis, K. R. (1991). Kantian "publicity" and political justice. History of Philosophy Quarterly, 8(4), 409-421.

Dean, J. (2008). Communicative capitalism: Circulation and the foreclosure of politics. In M. Boler (Ed.), Digital media and democracy: tactics in hard times (pp. 101-121). Cambridge, MA: The MIT Press.

Diamond, L., \& Plattner, M. F. (2012). Liberation technology: Social media and the struggle for democracy. Baltimore, MD: The Johns Hopkins University Press.

Ellul, J. (1964). The technological society. New York, NY: Vintage.

Etling, B., Faris, R., \& Palfrey, J. (2010). Political change in the digital age: The fragility and promise of online organizing. SAIS Review, 30(2), 37-49.

Foucault, M. (1979). Discipline and punish: The birth of the prison. New York: Vintage.

Fraser, N. (1993). Rethinking the public sphere: A contribution to the critique of actually existing democracy. In B. Robbins (Ed.), The phantom public sphere (pp. 1-32). Minneapolis: University of Minnesota Press.

Friedersdorf, C. (2014, August 18). Video killed trust in police officers. The Atlantic. Retrieved from http://www.theatlantic.com/national/archive/2014 /08/police-officers-havent-earned-our-instinctivetrust/378657

Galison, P. (1999). Objectivity is romantic. In J. Friedman, P. L. Galison, S. Haack, \& B. E. Frye (Eds.), The humanities and the sciences (pp. 15-43). Philadelphia: American Council of Learned Societies.

Goldsmith, A. J. (2010). Policing's new visibility. British Journal of Criminology, 50, 914-934.

Han, B.-C. (2012). Transparenzgesellschaft. Berlin, Germany: Matthes \& Seitz.

Harris, C. V. (2011). Technology and transparency as realist narrative. Science, Technology, \& Human Values, 36(1), 82-107.

Heald, D. (2006). Transparency as an Instrumental Value. In C. Hood \& D. Heald (Eds.), Transparency: The key to better governance? New York: Oxford University Press.

Herman, E. S., \& Chomsky, N. (2002). Manufacturing consent: The political economy of the mass media. New York: Pantheon Books.

Hier, S. (2003). Probing the surveillant assemblage: On the dialectics of surveillance practices as processes of social control. Surveillance \& Society, 1(3), 399-411.

Hier, S. P., Walby, K., \& Greenberg, J. (2006). Supplementing the panoptic paradigm: Surveillance, moral governance and CCTV. In D. Lyon (Ed.), Theorizing surveillance: The panopticon and beyond (pp. 23044). Portland, OR: Willan Publishing.

Hill, G. (2006). Rousseau's theory of human association: Transparent and opaque communities. New York: Palgrave Macmillan.

Hood, C. (2006). Transparency in historical perspective. In C. Hood \& D. Heald (Eds.), Transparency: The key to better governance? (pp. 3-23). New York: Oxford University Press.

Huey, L., Walby, K., \& Doyle, A. (2006). Cop watching in the downtown eastside: Exploring the use of (counter)surveillance as a tool of resistance. In T. Monahan (Ed.), Surveillance and security: Technological politics and power in everyday life (pp. 149-165). New York, NY: Routledge.

Independent Commission on the Los Angeles Police Department. (1991). Report on the independent commission on the Los Angeles police department. Los Angeles: Independent Commission on the Los Angeles Police Department.

Jalbert, K., Kinchy, A. J., \& Perry, S. L. (2014). Civil society research and marcellus shale natural gas development: Results of a survey of volunteer water monitoring organizations. Journal of Environmental Studies and Sciences, 4(1), 78-86.

Jeffries, J. (2011). Democracy for the few: How local governments empower cops at citizens' expense. Journal of Law and Conflict Resolution, 3(5), 71-75.

Jenkins, H. (2008). Convergence culture: Where old and new media collide (Revised ed.). New York: New York University Press.

Johnson, D., \& Regan, P. (2014). Transparency and surveillance as sociotechnical accountability: $A$ house of mirrors. New York: Routledge.

Kane, R. J. (2005). Compromised police legitimacy as a predictor of violence crime in structurally disadvantaged sommunities. Criminology, 43(2), 469-498.

Kinchy, A. J., \& Perry, S. L. (2012). Can volunteers pick up the slack? Efforts to remedy knowledge gaps about the watershed impacts of marcellus shale gas development. Duke Environmental Law \& Policy Forum, 22, 303-339.

Kinchy, A., Jalbert, K., \& Lyons, J. (2014). What is volunteer water monitoring good for? Fracking and the plural logics of participatory science. Political Power and Social Theory, 27(2), 259-289. 
Kindy, K., \& Kelly, K. (2015, April 11). Thousands dead, few prosecuted. The Washington Post. Retrieved from http://www.washingtonpost.com/sf/investiga tive/2015/04/11/thousands-dead-few-prosecuted

Koskela, H. (2003). "Cam Era": The contemporary urban panopticon. Surveillance \& Society, 1(3), 292313.

Koskela, H. (2006). "The other side of surveillance": Webcams, power and agency. In D. Lyon (Ed.), Theorizing surveillance: The panopticon and beyond (pp. 163-181). Portland: Willan Publishing.

Kraska, P. B., \& Kappeler, V. E. (1997). Militarizing American police: The rise and normalization of paramilitary units. Social Problems, 44(1), 1-18.

Lawrence, R. G. (2000). The politics of force: Media and the construction of police brutality. Berkeley, CA: University of California Press.

Leon, H. (2011, October 10). Cop punches occupy wall street protester: The whole world is watching! SFGate. Retrieved from http://blog.sfgate.com/ hleon/2011/10/14/cop-punches-occupy-wallstreet-protester-the-whole-world-is-watching

Lersch, K., \& Mieczkowski, T. (2005). Violent police behavior: Past, present, and future research directions. Aggression and Violent Behaviour, 10, 552568.

Levi, M., Sacks, A., \& Tyler, T. (2009). Conceptualizing legitimacy, measuring legitimating beliefs. American Behavioral Scientist, 53(3), 354-375.

Lyon, D. (2001). Surveillance society: Monitoring everyday life. Buckingham: The Open University Press.

Lyon, D. (2006). The search for surveillance theories. In D. Lyon (Ed.), Theorizing surveillance: The panopticon and beyond (pp. 3-20). Portland, OR: Willan Publishing.

Lyon, D. (2007). Surveillance studies: An overview. Malden: Poliy.

Machin, D. J. (2012). Political legitimacy, the egalitarian challenge, and democracy. Journal of Applied Philosophy, 29(2), 101-117.

Malandrucco, G. (2012, June 7). Video is the new reality: One year after Flint Farmer was senselessly killed by Chicago police. The Enemy Within: Modern Policing Within a Global Perspective. Retrieved from http://www.uscop.org/video-is-the-new-realityone-year-after-flint-farmer-was-senselessly-killedby-chicago-police

Mann, S., Nolan, J., \& Wellman, B. (2003). Sousveillance: Inventing and using wearable computing devices for data collection in surveillance environments. Surveillance \& Society, 1(3), 331-355.

Marx, G. T. (2006). Soft surveillance: The growth of mandatory volunteerism in collecting personal information: "hey buddy can you spare a dna?" In T. Monahan (Ed.), Surveillance and security: Technological politics and power in everyday life (pp. 3756). New York: Routledge.
Marx, G. T. (2009). A tack in the shoe and taking off the shoe: Neutralization and counter-neutralization dynamics. Surveillance \& Society, 6(3), 294-306.

Mathiesen, T. (1997). The viewer society: Michel Foucault's "panopticon" revisited. Theoretical Criminology, 1(2), 215-234.

McChesney, R. (1997). Corporate media and the threat to democracy. New York, NY: Seven Stories Press.

McElroy, W. (2010, May 31). Are cameras the new guns? The Freeman: Foundation for Economic Education. Retrieved from http://fee.org/freeman/ detail/are-cameras-the-new-guns

McLuhan, M. (1965). Understanding media: The extensions of man. New York: Signet.

Meyer, R. (2015, April 8). The courage of bystanders who press "record". The Atlantic. Retrieved from http://www.theatlantic.com/technology/archive/2 015/04/the-courage-of-bystanders-who-pressrecord/389979

Miller, C. (2014, January 22). Connecticut cop sentenced to 30 months in prison after arresting priest for recording. Photography Is Not A Crime. Retrieved from http://photographyisnotacrime.com/ 2014/01/22/connecticut-cop-sentenced-30months-prison-arresting-priest-recording

Mincy, G. A. (2013, 12 11). Hot rocks from the peacekeepers, polemics from the public. Before it's news. Retrieved from http://c4ss.org/content/22918.

Mulgan, R. G. (2003). Holding power to account: Accountability in modern democracies. New York, NY: Palgrave Macmillan.

Neocleous, M. (2000). The fabrication of social order: $A$ critical theory of police power. Sterling, VA: Pluto Press.

Neubauer, R. (2011). Neoliberalism in the information age, or vice versa? Global citizenship, technology, and hegemonic ideology. tripleC, 9(2), 195-230.

Norris, C., \& Armstrong, G. (1999). The maximum surveillance society: The rise of CCTV. New York: Bloomsbury Academic.

O'Kane, R. H. (1993). Against legitimacy. Political Studies, 41(3), 471-487.

Olson, J. (2004). The abolition of white democracy. Minneapolis, MN: University of Minneapolis Press.

Ottinger, G. (2010). Buckets of resistance: Standards and the effectiveness of citizen science. Science, Technology, \& Human Values, 35(2), 244-270.

Prenzler, T., \& Ronken, C. (2001). Models of police oversight: A critique. Policing and Society, 11(2), 151-180.

Reiner, R. (2010). The politics of the police (4 ${ }^{\text {th }}$ ed.). New York, NY: Oxford University Press.

Rojek, J., Alpert, G. P., \& Smith, H. P. (2012). Examining officer and citizen accounts of police use-of-force incidents. Crime \& Delinquency, 58(2), 301-327.

Rousseau, J.-J. (1913). The social contract \& discourses. London: J.M. Dent \& Sons, Ltd. 
Schlosberg, J. (2013). Power beyond scrutiny media, justice and accountability. New York: Pluto Press.

Schwartz, L.-G. (2009). Mechanical witness: A history of motion picture evidence in U.S. courts. New York, NY: Oxford University Press.

Sekula, A. (1978). Dismantling modernism, reinventing documentary (notes on the politics of representation). The Massachusetts Review, 19(4), 859-883.

Sen, S. (2010). Enforcing police accountability through civil oversight. Thousand Oaks, CA: Sage.

Skolnick, J. H., \& Fyfe, J. J. (1993). Above the law: Police and the excessive use of force. New York, NY: The Free Press.

Steele, R. D. (2012). The open-source everything manifesto: Transparency, truth, and trust. Berkeley: Evolver Editions.

Szarkowski, J. (2007). The photographer's eye (Reprint ed.). New York, NY: The Museum of Modern Art.

Taibbi, M. (2014, December 5). The police in America are becoming illegitimate. Rolling Stone. Retrieved from http://www.rollingstone.com/politics/news/ the-police-in-america-are-becoming-illegitimate20141205

Teurlings, J., \& Stauff, M. (2014). Introduction: The transparency issue. Cultural Studies $\leftrightarrow$ Critical Methodologies, 14(1), 3-10.

Thompson, J. B. (2005). The new visibility. Theory, Culture \& Society, 22(6), 31-51.

Thompson, B. L., \& Lee, J. D. (2004). Who cares if police become violent? Explaining approval of police use of force using a national sample. Sociological Inquiry, 74(3), 381-410.

Toch, H. (2012). Cop watch: Spectators, social media, and police reform. Washington, DC: American Psychological Association.
Torpey, J. (2000). The invention of the passport: Surveillance, citizenship and the state. Cambridge: Cambridge University Press.

Turilli, M., \& Floridi, L. (2009). The ethics of information transparency. Ethics and Information Technology, 11(2), 105-112.

Tyler, T. R. (2006). Psychological perspectives on legitimacy and legitimation. Annual Review of Psychology, 57, 375-400.

Tyler, T. R., \& Fagan, J. (2008). Legitimacy and cooperation: Why do people help the police fight crime in their communities? Ohio State Journal of Criminal Law, 6, 231-275.

Walker, S. E. (2005). The new world of police accountability. Thousand Oaks, CA: Sage Publications.

WeAreChange. (2013, August 23). Cop blocking with Pete Eyre in NYC. YouTube. Retrieved from https://www.youtube.com/watch?v=jmfBfH2Wrnk

Weitzer, R. (2002). Incidents of police misconduct and public opinion. Journal of Criminal Justice, 30, 397408.

Wilson, D., \& Serisier, T. (2010). Video activism and the ambiguities of counter-surveillance. Surveillance \& Society, 8(2), 166-180.

Winner, L. (1986). Mythinformation. In The whale and the reactor: $A$ search for limits in an age of high technology (pp. 98-117). Chicago, IL: University of Chicago Press.

Yesil, B. (2011). Recording and reporting: Camera phones, user-generated images and surveillance. In ICTs for mobile and ubiquitous urban infrastructures: Surveillance, locative media, and global networks (pp. 272-293). Hershey, PA: IGI Global.

Žižek, S. (2011, January 20). Good manners in the age of WikiLeaks. London Review of Books, 33(2), 9-10.

\section{About the Author}

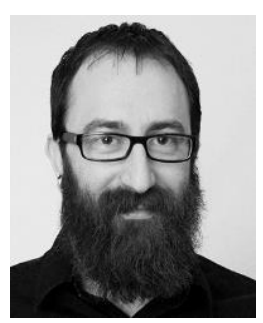

\section{Dr. Ben Brucato}

Ben Brucato is an interdisciplinary scholar and political theorist, working at intersections of media, technology, surveillance, policing, and race. Currently a postdoctoral fellow in the Center for Humanistic Inquiry at Amherst College, he works on the Mattering Lives project. Brucato earned his Ph.D. in Science \& Technology Studies from Rensselaer Polytechnic Institute. 